\title{
EVALUATION OF ALPHA FETOPROTEIN LEVELS AS A RISK FACTOR IN VIRAL HEPATITIS IN NORTHERN KERALA
}

Meghamol P. C, Sherin Stephen

1. MSC Biochemistry Student, Department of Biochemistry, Academy of Medical Sciences, Pariyaram, Kannur, Kerala

2. Professor, Department of Biochemistry, Academy of Medical Sciences, Pariyaram, Kannur, Kerala

\section{CORRESPONDING AUTHOR}

Dr. Sherin Stephen,

Professor,Department of Biochemistry,

Academy of Medical Sciences,Pariyaram,

Kannur, Kerala-670503

E-mail: sherin.stephen@rediffmail.com,

Ph: 00919947808143.

ABSTRACT: The manifestation of acute viral hepatitis is similar regardless of etiologic agent, but has important differences in terms of virology, epidemiology, and chronic sequelae. Hepatocellular carcinoma (HCC) is estimated to have an annual worldwide incidence of 0.25 to 1.2 million new cases per year. Both the prevalence and incidence of HCC vary markedly as a function of geography and the local prevalence of chronic viral hepatitis. Both hepatitis $\mathrm{B}$ and $\mathrm{C}$ are recognized as risk factors for HCC. The aim of the study is to assess the risk of hepatocellular carcinoma using AFP in viral hepatitis. The specific objectives are to find out comparison and correlation of parameters used in the study. The present study group consists of 80 patients and 20 controls. Serum AFP levels, bilirubin total, bilirubin direct, SGPT, SGOT, ALP, total protein, Albumin, Globulin, A/G ratio were investigated. The mean AFP level were 46.56 in patients and 1.3 in controls and is statistically significant. Except ALP, all other parameters are statistically significant. The AFP level in viral hepatitis patient was significantly correlated to the total bilirubin and direct bilirubin levels in patients. But no statistically significant correlation with SGPT, SGOT, ALP, total protein, Albumin, Globulin levels in patients. The serum alpha fetoprotein levels were found to be elevated and statistically significant in the patients under study. Hence AFP can be used as a marker for risk evaluation of hepatocellular carcinoma in viral hepatitis patients.

KEY WORDS: alpha fetoprotein, viral hepatitis, SGPT, hepatocellular carcinoma

INTRODUTION: Viral hepatitis is an important cause of morbidity and mortality worldwide ${ }^{1}$. It is caused by five well characterized hepatotropic agents, they are hepatitis A, B, C, Delta \& E viruses ${ }^{2}$. Hepatocellular carcinoma (HCC) is estimated to have an annual worldwide incidence of 0.25 to 1.2 million new cases per year ${ }^{3}$. Viral hepatitis is leading cause of liver cancer and the most common reason for liver transplantation*. Alpha fetoprotein (AFP), an albumin like glycoprotein is formed in yolk sac, non differentiated liver cells fetal gastro intestinal tract. AFP is normally used as tumor marker for primary hepatocellular carcinoma and germ cell tumors. As the AFP values rise during regeneration of liver moderately; elevated values are found in alcohol mediated liver cirrhosis and acute viral hepatitis as well as carriers of HBs Ag (hepatitis B surface antigen) ${ }^{5}$. Multiple factors are involved in the molecular pathogenesis of hepatocellular carcinoma (HCC). The activation of cellular oncogenes, the inactivation of tumor suppressor genes and over expression of certain growth factors contribute to the development 
of HCC. There is increasing evidence that the hepatitis B virus may play a direct role in molecular pathogenesis of HCC $^{6}$. Aspartate Transaminase (AST) and Alanine Transaminase (ALT) are the most commonly used markers of hepatocyte injury. ALT levels often rise to several thousands units per liter in patients with acute viral hepatitis. Patients with cirrhosis often have normal or only slightly elevated serum AST and ALT levels ${ }^{7}$.

In present study, AFP was used as a marker for the risk evaluation of hepatocellular carcinoma in viral hepatitis patients and correlation of AFP with liver enzymes was also evaluated.

MATERIALS AND METHODS: The present study group consists of 80 patients and 20 controls between age group 18-85. Blood samples from patients with viral hepatitis in Pariyaram, Medical College Kannur, from April 2012 to July 2012 were included for the study with their consent. All these cases were screened either for HBs Ag or Anti HAV or Anti HCV and all positive cases were considered as patients. Those who were negative for HBs Ag, Anti HAV and Anti HCV were considered as control group. Detailed baseline clinical data of each patient including age, sex, present and past clinical complaints, family history and associated complaints were noted.

The following biochemical tests were done in patients and controls included in the study like, determination of serum alpha fetoprotein, serum total and direct bilirubin level, serum SGPT, SGOT, total protein, albumin, globulin and A/G ratio. All investigations were done using AU400 Beckmann fully automated analyzer and the Roche diagnostics Elecsys 2010 immunoassay system. .Statistical analysis is done using SPSS 17.0

RESULT: The present study group consists of 80 patients and 20 controls between age group of 18-85, who were referred to Medical College Hospital Pariyaram, during the period from April 2012-July 2012.

In the study group, 3 female patients were less than 20 years of age, 5 female patients belonged to 20-30 years age group, 4 female patients each were in the age group 30-40 years and 40-50 years respectively and 9 female patients were more than 50 years old. Among the male patients studied, 12 belonged to the age group 20-30 years, 8 were in the age group 30-40 years, 9 were in the age group 40-50 years and 26 were in the age group of more than 50 years. In the control group, only 1 female belonged to age group 20-30 and 30-40 years and 3 female controls were more than 50 years. Among the male controls, 2 belonged to the age group 20-30 years, 3 were in age group 30-40 years, 6 were in age group 40-50 years and 9 were in the age group of more than 50 years.

Mean level of total bilirubin in patient is $3.24 \mathrm{mg} / \mathrm{dL}$ and mean level in control is $0.68 \mathrm{mg} / \mathrm{dL}$. The p-value is $<0.05$, so it is statistically significant. The P-value of direct bilirubin is $<0.05$, which is statistically significant. The mean level of direct bilirubin in the patients is 1.40 and in control is $0.12 \mathrm{mg} / \mathrm{dL}$. The SGPT level is statistically significant with a P-value 0.023 . The mean value of SGPT in patients is $163.39 \mathrm{IU} / \mathrm{L}$ and in control is $26.4 \mathrm{IU} / \mathrm{L}$. The mean value of SGOT in patients is $177.72 \mathrm{IU} / \mathrm{L}$ and in control is $23.55 \mathrm{IU} / \mathrm{L}$. The P-value of SGOT is $<0.05$, which is statistically significant. The P-value of ALP is $>0.05$, so it is not statistically significant. The mean level of ALP in patients is 139.49IU/L and in control is 69.65IU/L. The P-value of total protein is 0.005 , so it is statistically significant. The mean level of total protein in patients is $7.3 \mathrm{~g} / \mathrm{dL}$ and in control is $7.8 \mathrm{~g} / \mathrm{dL}$. The P-value of albumin is 0.05 ,so it is statistically significant. The mean value of albumin in patients is $3.8712 \mathrm{~g} / \mathrm{dL}$ and in contact is $4.625 \mathrm{~g} / \mathrm{dL}$. The P-value of 
globulin is 0.009 so it is statistically significant. The mean level is $3.4188 \mathrm{~g} / \mathrm{dL}$ and in contact is $3.175 \mathrm{~g} / \mathrm{dL}$.

DISCUSSION: In the present study serum alpha fetoprotein levels were significantly higher in patients with viral hepatitis than control and was statistically significant $(\mathrm{P}=0.037)$. The total and direct bilirubin, SGPT and SGOT levels were higher in patients than control and statistically significant. The ALP level were higher in patients but not statistically significant $(\mathrm{P}=0.051)$. The total protein and albumin levels were slightly lower in patients than control and statistically significant. The globulin levels in patients were higher than control and statistically significant $(\mathrm{P}=0.009)$.

The AFP levels were positively correlated with total and direct bilirubin levels in patients and also statistically significant $(\mathrm{P}<0.01)$. The AFP levels has a correlation with SGPT, SGOT, ALP, total protein, albumin and globulin but not statistically significant $(\mathrm{P}>0.01)$.

Thus, in the present study, AFP levels correlate well with the extent of liver damage as indicated by the rise in liver enzyme levels as well.

\section{REFERENCE:}

1. Richard L Guerrant, David H Walker, Peter F Weller Trophical infectious diseases, principles, pathogens, and practice.2000; $2^{\text {nd }}$ edition, vol 1:694-720.

2. Arrieta O, Rodríguez-Díaz J, Rosas-Camargo V, Morales-Espinosa D, Ponce de León S, Kershenobich D, et al. Colchicine delays the development of hepatocellular carcinoma in patients with hepatitis virus related-liver cirrhosis. Cancer 2006; 107: 1852-8

3. Idilman R, De Maria N, Colantoni A, Van Thiel DH. Pathogenesis of hepatitis B and C induced hepatocellular carcinoma. Journal of viral hepatitis 1998;5:285-299.

4. Alter MJ, Mast EE. The epidemiology of viral hepatitis in the United States. Gastro Clin North Am 1994;23:437-457.

5. Carl A Burtes, Edward R Ashwood, David E Bruns. Tietz textbook of clinical chemistry and molecular diagnosis. $20064^{\text {th }}$ edition;766-768.

6. Moradpur D, Wands JR. The molecular pathogenesis of hepatocellular carcinoma. Journal of viral hepatitis 1994; 1:17-31.

7. Kamath P S. Clinical approach to the patients with abnormal liver function test results Mayo Clin Proc 199 ; 71:1089-1094.

\section{Variation between the patients and control group with AFP level}

\begin{tabular}{|ll|c|c|c|c|}
\hline & & & & & \\
\hline AFP & PROUP & $\mathrm{N}$ & MEAN & STD. DEVIATION & P-VALUE \\
& & 80 & 46.57 & 183.67 & 0.037 \\
& CONTROL & 20 & 1.30 & 0.45 & \\
\hline
\end{tabular}

This table gives group statistics of parameters of patients and control. The mean level of AFP in patients is $46.57 \mathrm{ng} / \mathrm{mL}$ and mean level in control is $1.30 \mathrm{ng} / \mathrm{mL}$. The P-value is $<0.05$, so it is statistically significant. 
Correlation of AFP with different parameters

\begin{tabular}{|c|c|c|c|}
\hline & & BB TOTAL & AFP \\
\hline \multirow[t]{4}{*}{ AFP } & Pearson Correlation & 0.404 & 1 \\
\hline & Sig. (2-tailed) & 0 & \\
\hline & $\mathbf{N}$ & 80 & 80 \\
\hline & & BB DIRECT & AFP \\
\hline \multirow[t]{4}{*}{ AFP } & Pearson Correlation & 0.321 & 1 \\
\hline & Sig. (2-tailed) & 0.004 & \\
\hline & $\mathbf{N}$ & 80 & 80 \\
\hline & & SGPT & AFP \\
\hline \multirow[t]{4}{*}{ AFP } & Pearson Correlation & -0.057 & 1 \\
\hline & Sig. (2-tailed) & 0.617 & \\
\hline & $\mathbf{N}$ & 80 & 80 \\
\hline & & SGOT & AFP \\
\hline \multirow[t]{4}{*}{ AFP } & Pearson Correlation & 0.004 & 1 \\
\hline & Sig. (2-tailed) & 0.969 & \\
\hline & $\mathbf{N}$ & 80 & 80 \\
\hline & & ALP & AFP \\
\hline \multirow[t]{3}{*}{ AFP } & Pearson Correlation & 0.124 & 1 \\
\hline & Sig. (2-tailed) & 0.272 & \\
\hline & $\mathbf{N}$ & 80 & 80 \\
\hline
\end{tabular}

Correlation of AFP with different parameters

\begin{tabular}{|l|l|r|r|}
\hline & & \multicolumn{1}{|c|}{ TOTAL } & 80 \\
\hline AFP & Pearson Correlation & -0.144 & 1 \\
\hline & Sig. (2-tailed) & 0.203 & \\
\hline & N & 80 & \\
\hline & & ALBUMIN & AFP \\
\hline AFP & Pearson Correlation & -0.156 & 1 \\
\hline & Sig. (2-tailed) & 0.166 & 80 \\
\hline & N & 80 & 1 \\
\hline AFP & & GLOBULIN & AFP \\
\hline & Pearson Correlation & 0.041 & 80 \\
\hline & Sig. (2-tailed) & 80 & \\
\hline & N & & \\
\hline
\end{tabular}




\section{ORIGINAL ARTICLE}

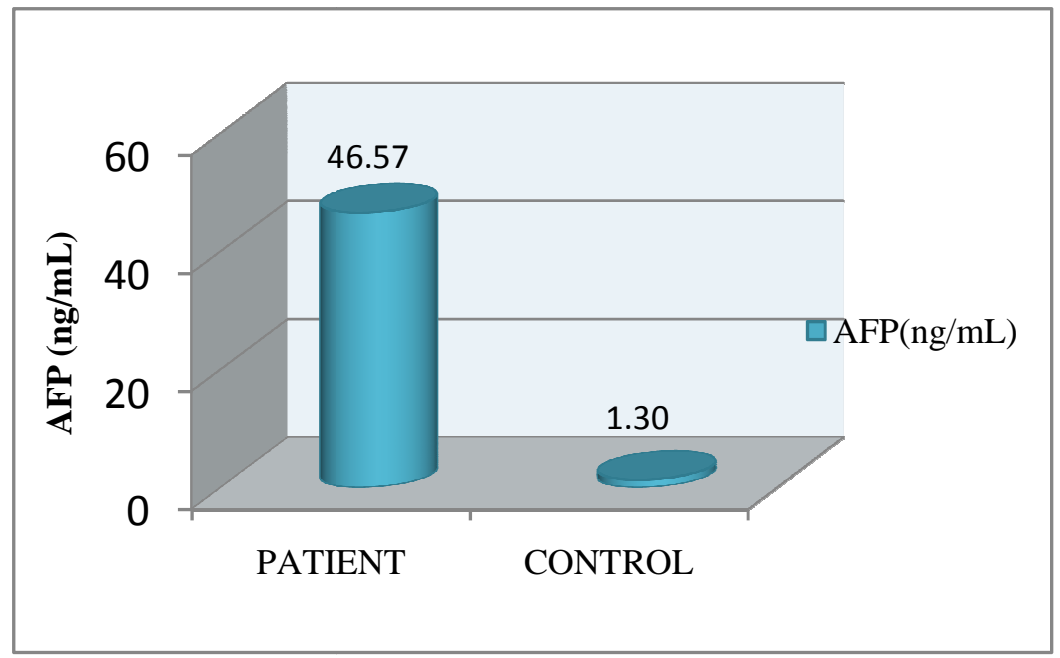

Variation between the patients and control group with AFP level 